\title{
Studi Kasus: Penerapan Padma Sebagai Terapi Untuk Menstimulasi Tumbuh Kembang Anak Down Sindrom
}

\author{
Rika Harini \\ Dosen Keperawatan Anak STIKES Bani Saleh \\ Email: rika@stikesbanisaleh.ac.id
}

\begin{abstract}
Abstrak
Kejadian down sindrom selama 17 tahun terakhir meningkat cukup pesat dengan perbandingan 1:700 kelahiran hidup. Jumlah anak penderita down sindrom di dunia mencapai 8 juta kasus dan di Indonesia diperkirakan lebih dari 3 tiga ribu kasus. Anak down sindrom memiliki masalah dalam tumbuh kembangnya yang berbeda dan terlambat dibandingkan dengan anak normal, sehingga memerlukan terapi khusus salah satunya adalah Padma. Padma adalah Pijat Anak Down sindrom Mastakaraga Shobia, merupakan jenis terapi pijat yang memberikan stimulasi pada jalur-jalur sensori sumsum tulang dan kepala secara lembut melalui jalur persyarafan dan pembuluh darah melalui sub terminal tubuh dengan tujuan tercapainya kelancaran dan keseimbangan proses dalam tubuh. Karya ilmiah ini menggunakan metode survey deskriptif dengan pendekatan studi kasus. Didapatkan hasil positif terhadap perkembangan anak down sindrom setelah diberikan terapi Padma. Keseimpulan: terapi Padma sangat efektif dalam menstimulasi tumbuh kembang anak down sindrom. Saran: Terapi Padma dapat menjadi salah satu terapi komplementer untuk menstimulasi tumbuh kembang anak down sindrom.
\end{abstract}

Kata Kunci: Pijat; Down Sindrom; Padma

\begin{abstract}
The incidence of down syndrome during the last 17 years has increased quite rapidly with a ratio of 1:700 live births. The number of children with Down syndrome in the world reaches 8 million cases and in Indonesia it is estimated that more than 3 three thousand cases. Children with Down syndrome have problems in growth and development that are different and late compared to normal children, so that requires special therapy, one of which is Padma. Padma is a Child Down Massage of Mastakaraga Shobia syndrome, a type of massage therapy that provides stimulation of the sensory pathways of the bone marrow and head gently through nerve supply and blood vessels through the sub-terminal of the body with the aim of achieving smooth and balance processes in the body. This scientific work uses descriptive survey method with a case study approach. Positive results were obtained for the development of Down syndrome children after being given Padma therapy. Conclusion: Padma therapy is very effective in stimulating the growth and development of children with Down syndrome. Suggestion: Padma therapy can be one of the complementary therapies to stimulate the growth and development of children with Down syndrome.
\end{abstract}

Key words: Massage; Down Syndrome; Padma 


\section{PENDAHULUAN}

Down syndrome adalah suatu kondisi keterbelakangan perkembangan fisik dan mental pada anak yang disebabkan adanya abnormalitas perkembangan kromosom (Cuncha (1992). Gunarhadi (2005) mendefinisikan down sindrom sebagai kumpulan gejala akibat dari abnormalitas kromosom, biasanya kromosom 21, yang tidak dapat memisahkan diri selama meiosis sehingga terjadi individu dengan 47 kromosom. Kejadian down sindrom dari clinic for children dalam 17 tahun terakhir meningkat cukup pesat dengan perbandingan 1:700 kelahiran hidup. Jumlah anak penderita down sindrom di dunia mencapai 8 juta kasus dan di Indonesia diperkirakan lebih dari 3 ribu kasus $(3,75 \%)$ dari populasi anak down sindrom di dunia. Namun jumlah ini belum diketahui secara pasti karena data anak penyandang down sindrom di Indonesia belum terdokumentasi dengan pasti (Masduki, A, 2019).

Anak down sindrom memiliki banyak masalah yang berhubungan tumbuh kembangnya meliputi ukuran tubuh pendek, keterlambatan kognitif, bahasa dan interaksi sosial, mototrik kasar dan halus (Megasari \& Kristiana, 2016). Selain itu persepsi masyarakat yang menganggap mereka anak aneh, dikucilkan oleh lingkungan bermain dan tidak bisa ikut serta menjadi bagian dalam berbagai hal (Renawati,. Darwis.,\& Wibowo, 2017). Banyaknya permasalahan pada anak down sindrom sering membuat ibu merasa kesulitan dan cemas dalam perawatan anaknya dan dapat berakibat munculnya depresi pada pengasuhan anak (Zeisler, 2011).
Glenn Doman, ahli fisik dan terapi pendiri Institute for The Achievement of Human Potential, yang banyak menangani anak down sindrom, menyatakan bahwa anak down sindrom disebabkan oleh otak yang cidera. Lokasi atau area tubuh yang perlu diterapi adalah jalur sensori manusia yang berada di sebelah sumsum tulang belakang dan otak bagian belakang. Kemampuan sensorik ini meliputi penerimaan informasi melalui kelima indra, yaitu penglihatan, pendengaran, penciuman, perabaan, dan pengecap. (http://eramuslim.com/konsultasi/anakluar-biasa/apakah-downsyndrome akibat-penyakit-keturunan.htm).

Terapi pada anak down sindrom bertujuan meningkatkan kemandirian anak. Jenis terapi yang diberikan pada anak down sindrom adalah terapi fisik (Physio therapy), terapi wicara, terapi okupasi, terapi remedial, terapi sensori integrasi, terapi tingkah laku (behaviour therapy), terapi akupunktur, terapi musik, terapi lumba-lumba dan terapi craniosacral (Gunarhadi, 2005). Dalam pelaksanaannya, terapi tersebut tidaklah murah dan masih dibutuhkan kombinasi dari jenis terapi lain untuk dapat memaksimalkan dan mempercepat tumbuh kembang anak down sindrom, selain itu juga murah sehingga dapat menjangkau seluruh lapisan masyarakat.

Terapi Padma dapat dijadikan sebagi solusi menstimulasi tumbuh kembang anak down sindrom. Penelitian penerapan teknik terapi Padma memang masih belum ada karena ilmu terapi pijat ini ditemukan pada tahun 1997 oleh anak bangsa Indonesia asli di Bekasi. Namun secara empiris, teknik ni terbukti membantu mempercepat tumbuh dan kembang pada anak berkebutuhan khusus diberbagai daerah baik dalam 
Studi Kasus: Penerapan Padma Sebagai Terapi Untuk Menstimulasi Tumbuh Kembang Anak Down Sindrom

maupun luar negeri. Karya Tulis Ilmiah (KTI) ini bertujuan untuk menggambarkan konsep, pelaksanaan dan hasil dari Terapi Padma dalam menstimulasi tumbuh kembang anak down sindrom.

\section{LITERATURE REVIEW}

\section{A. Konsep Anak Down Sindrom}

1. Pengertian

Down syndrome adalah suatu kondisi keterbelakangan perkembangan fisik dan mental pada anak yang disebabkan adanya abnormalitas perkembangan kromosom (Cuncha (1992). Gunarhadi (2005) mendefinisikan down sindrom sebagai kumpulan gejala akibat dari abnormalitas kromosom, biasanya kromosom 21, yang tidak dapat memisahkan diri selama meiosis sehingga terjadi individu dengan 47 kromosom. Dari pendapat pada ahli diatas dapat disimpulkan bahwa down sindrom adalah keterbelakangan fisik dan mental pada anak yang disebabkan oleh abnormalitas kromosom 21 sehingga terjadi individu dengan 47 kromosom.

2. Penyebab

Down sindrom disebabkan oleh abnormalitas perkembangan kromosom 21 dimana kromosom 21 memiliki 3 genom yang disebut dengan trisomy 21 (Gunarhadi, 2005).

3. Karakteristik Anak Down Sindrom Menurut Gunarhadi (2005), anak down sindrom memiliki karakteristik sebagai berikut:

1) Kekuatan otot lemah.

Ototnya begitu kendur sehingga kepala dan bagian

tubuhnya menjadi lunglai.Lengan dan kakinya lemas dan mudah digerakkan.Kekuatan otot yang lemah berdampak terhadap lambannya gerak daya kekuatan dan perkembangan secara umum.

2) Ciri-ciri kepala.

Kepala lebih kecil daripada umumnya, leher lebih pendek dibandingkan dengan leher bayi lainnya, lipatan atau kerutan kulit bayi mudah terlihat dibagian punggung dan leher, memiliki ubunubun yang sangat lunak dan lebih besar

3) Ciri-ciri wajah.

Muka datar dan lebih kecil, ujung mata miring ke atas, jarak antara kedua mata sangat jauh, terdapat banyak lipatan keriput kulit dikelopak mata, bercak putih pada iris mata, hidung lebih kecil dan pesek, mulut lebih sempit dan mulut bagian atas cenderung turun sehingga bibir atas cenderung lebih datar dibandingkan bibir bawah, ujung lidah lebih besar, daun telinga lebih kecil dan agak sedikit ke bawah, gigi lama muncul dan warna email berbeda dengan gigi anak normal

4) Ciri-ciri tangan dan kaki Jari tangan dan kaki sedikit lebih kecil, lebih pendek dan tumpul, jari tangan yang kelima (kelingking) terkadang menekuk ke dalam, jarak 
antara ibu jari kaki dan telunjuk lebar, garis tangan ada 1 (simian crease).

Masalah anak down sindrom sebagai berikut: Penyakit jantung mata (brushfield spots), posisi mata miring ke atas, adanya lipatan ekstra pada sudut mata (ephicanthal folds), lubang mulut kecil sehingga lidah cenderung menekuk, tangan pendek tetapi lebar dengan lipatan tunggal pada telapak tangan (simian crease), dan jarak lebar antara ibu jari dan telunjuk

\section{B. Konsep Terapi Pijat}

\section{Pengertian}

Terapi pijat bayi diartikan sebagai proses mengusap-usap otot dan menyentuh bayi sesuai dengan petunjuk khusus yang disusun untuk bayi (Auckett, 2004). Hal yang sama juga disampaikan oleh Pardew (1996) bahwa terapi pijat bayi adalah proses sistematis meliputi mengusap, membelai, dan meremas kaki bayi, perut, dada, bahu, lengan, leher, wajah, dan kepala.

2. Manfaat

Roesli (2008) mengatakan, manfaat biokimia positif meliputi penurunan kadar hormon stres (catecholamine) dan peningkatan kadar zat daya tahan tubuh (immunoglobulin) terutama $\mathrm{IgG}$, IgA, dan IgM. Dan manfaat klinis positif yaitu peningkatan jumlah sel dan daya racun (sitotosisitas) dari sistem imunitas (sel pembunuh alami/natural killer cells), mengubah gelombang otak secara positif, memperbaiki bawaaan, gangguan mental, tubuh kecil, kekuatan otot lemah (hipotonia), kelenturan yang tinggi pada persendian, bercak pada iris

sirkulasi darah dan pernafasan, merangsang fungsi pencernaan dan pembuangan, meningkatkan kenaikan berat badan, mengurangi depresi dan ketegangan, meningkatkan kesiagaan, membuat bayi tidur lelap, mengurangi rasa sakit, kembung dan kolik, meningkatkan hubungan orangtua dan bayi (bonding), dan meningkatkan volume ASI. Coulter (1999) menambahkan bahwa pijat bayi juga bermanfaat untuk ibu dalam hal mempererat hubungan kedekatan antara ibu dengan bayi dan ibu lebih mudah memahami isyarat yang diberikan oleh bayi.

3. Mekanisme Efek pijat

Weerapong, et al (2005) menjelaskan bahwa mekanisme pijat dapat memberikan efek secara biomekanikal tubuh, fisiologikal, neurologikal, dan psikologikal. Adapun pengaruh efek pijat tersebut adalah: 1) Efek biomekanikal tubuh dapat mengurangi adesi jaringan dan peningkatan kemampuan otot sehingga otot tidak kaku, 2) efek fisiologikal menyebabkan peningkatan suhu permukaan kulit dan otot setelah dipijat, meningkatkan aliran darah, menstimulasi aktifitas parasimpatis dengan mengurangi jumlah cortisol didalam saliva, aktifitas parasimpatis dapat menurunkan frekuensi jantung, 
Studi Kasus: Penerapan Padma Sebagai Terapi Untuk Menstimulasi Tumbuh Kembang Anak Down Sindrom

tekanan darah, meningkatkan relaksasi dengan pelepasan hormon endorphine, 3) efek neurologikal akan menstimulasi sensor penerima dan menurunkan ketegangan otot melalui pengurangan rangsangan pada terhadap penurunan kecemasan, meningkatkan relaksasi dan menyembuhkan kelemahan.

4. Kontra indikasi pijat

Kontra indikasi pijat dibagi kedalam dua kelompok, yaitu kontra indikasi lokal (local contraindication) dan kontra indikasi mutlak (absolute contraindication) dan sementara. Kontra indikasi lokal berarti pasien hanya mendapatkan terapi pijat di area-area tubuh tertentu diluar area bermasalah, seperti pada kasus infeksi jamur kronis, lepuh, memar, kolitis, crohn's disease, cystitis, ulkus dekubitus, hernia, dan lain-lain. Sedangkan kontra indikasi mutlak merupakan kondisi dimana pasien tidak boleh menerima pijatan. Kondisi ini meliputi deep vein thrombosis (DVT), sirosis hati, hipertensi tak terkendali, obstruksi usus, gagal ginjal, limfangitis, miokarditis, perikarditis, embolisme pulmoner, SARS, sinkope dan TBC. Sedangkan kontra indikasi sementara adalah cacar air, dermatitis kontak (jika luas), demam, campak jerman, gout (selama fase akut), hepatitis, hipertensi (kecuali dikendalikan oleh obat, diet atau olahraga) influenza (flu), kutu, lupus, campak, mononucleosis, gondongan, pneumonia, cedera neuromuskular, mengurangi rasa nyeri melalui mekanisme neurologikal (gate control theory), fisiologikal (substansi biokimia), dan mekanikal (mereposisi serat otot), 4) efek psikologikal mempengaruhi atau operasi baru, scabies, dan tonsilitis (Brownell, 2008).

\section{Terapi Pijat Padma}

1. Pengertian

Padma adalah singkatan dari Pijat anak down sindrom Mastakaraga shobia.

Matakaraga berasal dari bahasa sunda, yaitu Mastaka berarti kepala dan Raga artinya badan. Mastakaraga berarti memberikan terapi pijat dari kepala hingga seluruh tubuh.

Shobia adalah kepanjangan dari Sindrom Hiper for Balita dan Anak, merupakan bagian dari terapi pijat mastakaraga dengan kekhususan pada anak berkebutuhan khusus. Padma adalah nama khusus untuk terapi yang diberikan pada anak down sindrom.

2. Tujuan: Memberikan stimulasi tumbuh kembang pada anak down sindrom.

3. Manfaat: Menstabilkan tanda vital anak, melancarkan sirkulasi darah tubuh, memberikan kenyamanan pada anak, menstimulasi otot, syaraf, kelenjar, sirkulasi dan pencernaan tubuh, meningkatkan pertumbuhan dan perkembangan anak berkebutuhan khusus

4. Langkah-langkah 
1) Hasil pemeriksaan oleh tenaga medis (jika ada)

2) Persiapan psikologis terapis, orangtua dan anak

3) Persiapan tempat/ruangan: pencahayaan cukup terang, tidak berisik, sirkulasi udara baik, tidak membahayakann anak

a. Terapis mencuci tangan

b. Terapis melakukan pendekatan dan minta ijin pada anak

c. Periksa tanda vital anak: nadi, pernafasan, suhu tubuh dan tekanan darah (bila perlu) dan pertumbuhan dan perkembangan anak atau keluhan anak

d. Mulailah pijatan pada area yang disukai anak dan hindarkan pemijatan yang menyakitkan atau pemaksaan satu posisi yang tidak nyaman bagi anak diawal pemijatan

e. Lakukan pemijatan mencakup area kepala, tulang belakang, sacral, otot, pencernaan dan kelenjar (sesuai dengan masalah klien). Pemijatan dilakukan dengan teknik usapan, tekanan, gerakan sirkuler, getaran, dan pompa.

f. Perhatikan respon anak selama dilakukan pijatan.

g. Ajak anak bercerita atau berbicara selama pemijatan
4) Peralatan: handuk kecil, wadah kecil tepat minyak terapi, minyak kayu putih, minyak kelapa (minyak tidak alergi pada anak), bawang merah, tissue, bantal, matras, tempat mencuci tangan

5) Langkah-langkah pelaksanaan:

h. Hadirkan orangtua selama proses pemijatan untuk kenyamanan anak

i. Beritahu anak bila pijatan sudah selesai

j. Rapikan dan bersihkan anak dari sisa minyak yang digunakan

k. Periksa kembali tanda vital anak

1. Rencanakan waktu untuk terapi kembali

m. Catat semua hal terkait klien dan tindakan yang dilakukan

n. Ucapkan terima kasih atas kerjasam anak selama pemberian pijat dan beri reward positif pada anak.

5. Contoh gerakan Padma

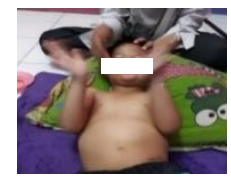

Palpasi nadi temporalis

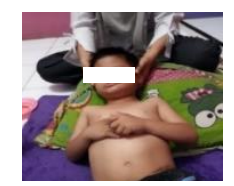

Stimulasi cerebelum

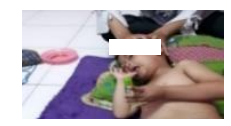

Stimulasi penyeimbangan in-out otak

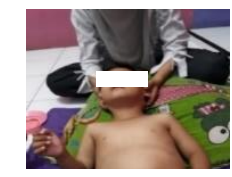

Membuka jalur oksigen ke otak

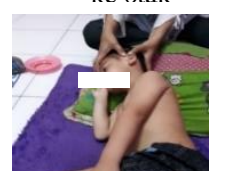

Stimulasi pendengaran \& konsentrasi

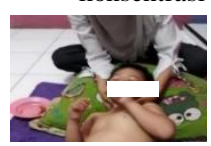

Stimulasi bicara 
Studi Kasus: Penerapan Padma Sebagai Terapi Untuk Menstimulasi Tumbuh Kembang Anak Down Sindrom

\section{METODOLOGI}

Metodologi menggunakan metode survey deskriptif dengan pendekatan studi kasus dalam menguraikan konsep, pelaksanaan dan hasil dari penerapan teknik Padma.

emosional tidak stabil, tidak mampu mempertahankan kontak mata dengan lawan bicara, tidak mengerti perintah sederhana, makan disuapi, belum bisa membedakan rasa makanan, belum bisa berfikir sederhana seperti cara mengambil benda, bercanda dengan teman, tubuh pendek, mudah terkena pilek dan mencret, belum punya inisiatif bila merasa haus dan lapar.

Hasil yang didapatkan penulis dari penerapan terapi Padma pada anak down sindrom adalah:

1) Setelah 1 x Pemijatan pada area kepala, diperoleh hasil terdapat kesamaan denyut nadi temporalis kanan dan kiri. Kesamaan kualitas dan frekuensi denyutan pada nadi menunjukkan sirkulasi pada area kepala yang telah lancar. Kelancaran sirkulasi pada area kepala membantu pemerataan distribusi oksigen dan peredaran darah sehingga bagian-bagian yang awalnya kosong atau tidak mendapatkan suplay menjadi teraliri oleh darah dan oksigen. Mempertahankan kelancaran sirkulasi kepala dapat membantu otak dalam memproses dan memahami informasi ataupun stimulus yang diberikan oleh lingkungan

2) Setelah 1 x Pemijatan pada area jantung, diperoleh hasil denyutan nadi menjadi penuh.

\section{HASIL DAN PEMBAHASAN}

Gambaran kondisi klien sebelum dilakukan terapi Padma adalah klien berusia 6 tahun dengan kondisi perilaku

Kualitas denyutan yang penuh mengindikasikan sirkulasi ke bagian tubuh lainnya yaitu kepala, jantung, paru, pencernaan, tangan dan kaki (seluruh tubuh) akan mampu menyuplai kebutuhan oksigen dan nutrisi keseluruh tubuh.

3) Setelah 4 x Pemijatan pada otot, didapatkan hasil konsistensi otot lebih padat, gerakan lebih terkendali, mampu menggerakkan ekstremitas secara terarah dan minimal cedera. Hal ini terjadi akibat sirkulasi pada otot dan persyarafan menjadi lancar dan adanya koordinasi gerak antara perintah diotak dan kemampuan untuk menggerakkan

4) Setelah $5 \mathrm{x}$ pemijatan Pemijatan pada tulang belakang dan sacrum, bertujuan untuk mengaktifkan persyarafan yang ada dijalur belakang tubuh yang menjadi pusat kegiatan sensoris dan motoris. Hasil yang didapatkan pada anak down sindrom adalah kontrol emosional anak menjadi lebih stabil, anak berespon terhadap stimulus yang diberikan oleh lingkungan dan tubuh.

5) Setelah 3 x Pemijatan pada area pencernaan bertujuan meningkatkan fungsi pencernaan. Hasil yang 
didapatkan adalah anak mulai bisa merasakan rasa makanan yang enak dan tidak enak, bisa menunjukkan rasa bosan terhadap makanan, mengerti dengan rasa lapar

6) Setelah 6 x Pemijatan pada area sistem limfatik bertujuan untuk meningkatkan imunitas tubuh. Hasil yang didapatkan adalah anak menjadi jarang terkena pilek dan demam Menurut Diego dan Field (2009) sentuhan dan masase merupakan teknik integrasi sensori yang mempengaruhiaktivitas sistem saraf otonom, sehingga meningkatkan aktivitas sistem saraf parasimpatis untuk mengeluarkan neurotransmitter seperti hormon endorphin, serotonin, dan asetilkolin. Melalui respon yang dihasilkan oleh otak, peningkatan serotonin dapat mengurangi efek psikis dari stres dan mengurangi efek psiko seperti perilaku tidak terkontrol. Kozier, et al (2010) mengatakan terapi masase dapat menstimulasi produksi kimiawi yang meningkatkan penyembuhan oleh sistem imun atau sistem limbik. Masase punggung dapat memperbaiki sirkulasi darah dan membantu relaksasi. Pendapat para peneliti ini sesuai dengan hasil yang didapatkan setelah pemberian terapi pada anak down sindrom

Tabel. 1

Jadwal Dan Target Pelaksanaan Home Care

\begin{tabular}{|c|c|c|c|c|c|c|}
\hline No & $\begin{array}{c}\text { Tgl/ja } \\
\mathbf{m}\end{array}$ & Kegiatan & $\begin{array}{l}\text { Hasil yang } \\
\text { diharapkan }\end{array}$ & Pencapaian & $\begin{array}{c}\text { Ttd } \\
\text { Pelaksa } \\
\text { na } \\
\end{array}$ & $\begin{array}{c}\text { Ttd } \\
\text { Keluarga }\end{array}$ \\
\hline 1 & $\begin{array}{c}04 \text { Des } \\
2018 \\
12.0 \\
13.00 \\
\text { wib }\end{array}$ & $\begin{array}{l}\text { Kontrak } \\
\text { kerja } \\
\text { dengan } \\
\text { keluarga }\end{array}$ & $\begin{array}{l}\text { Keluarga setuju } \\
\text { dengan kontrak } \\
\text { kerja } \\
\text { rencana yang } \\
\text { akan dijalankan }\end{array}$ & $\begin{array}{l}\text { Adanya kontak } \\
\text { kerja yang jelas } \\
\text { antara pelaksana } \\
\text { dengan keluarga }\end{array}$ & & \\
\hline
\end{tabular}


Studi Kasus: Penerapan Padma Sebagai Terapi Untuk Menstimulasi Tumbuh Kembang Anak Down Sindrom

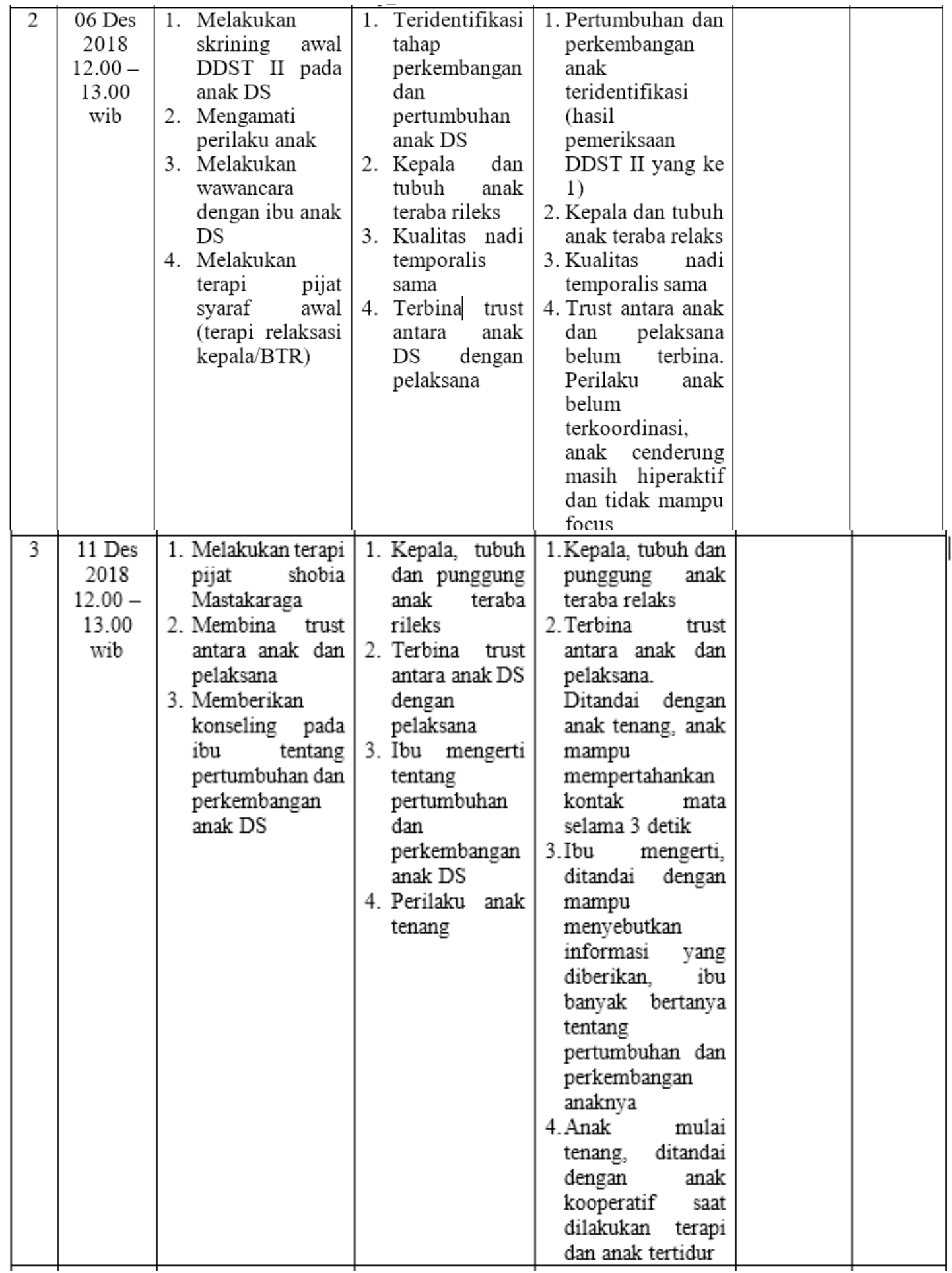




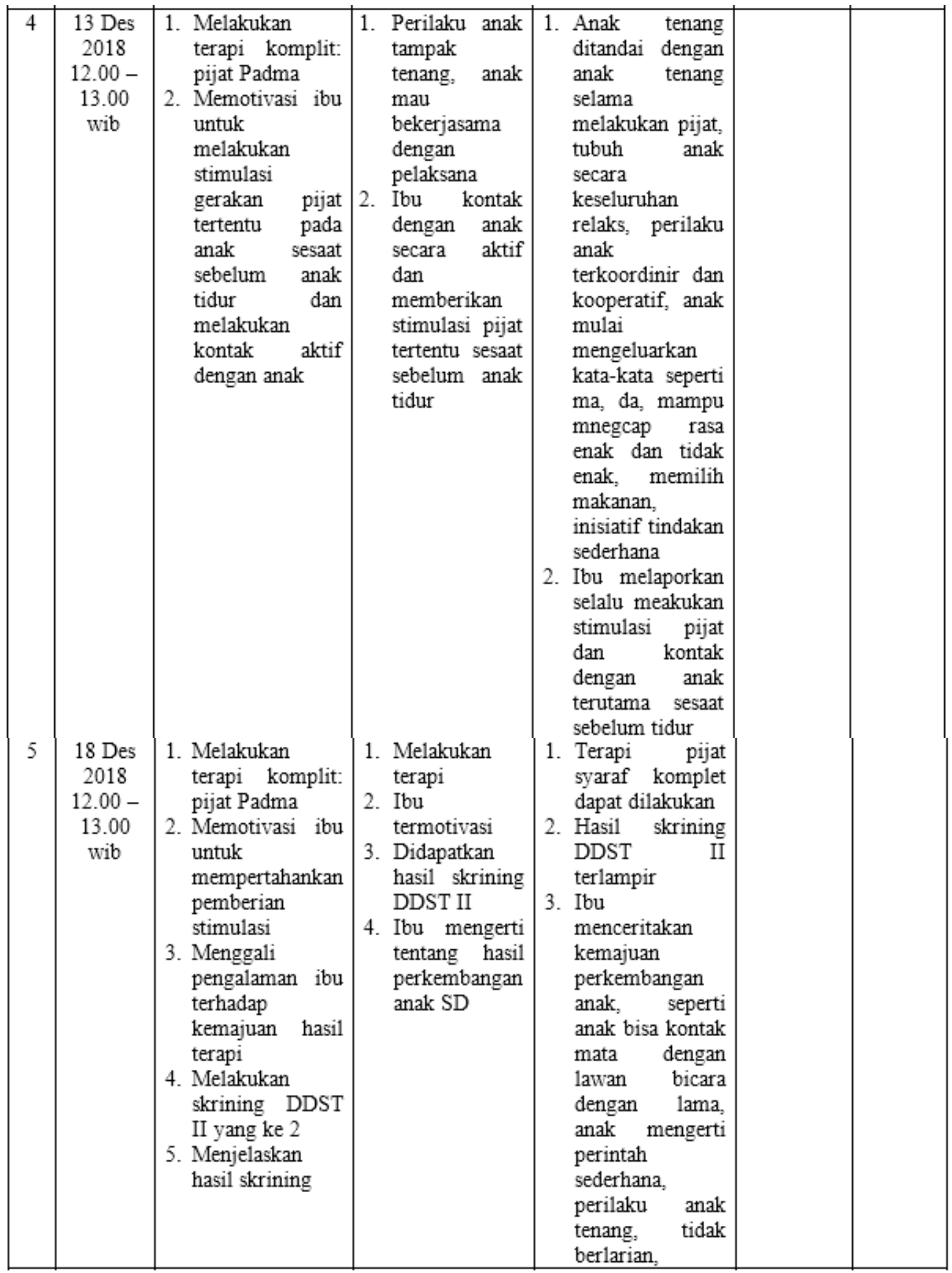


Studi Kasus: Penerapan Padma Sebagai Terapi Untuk Menstimulasi Tumbuh Kembang Anak Down Sindrom

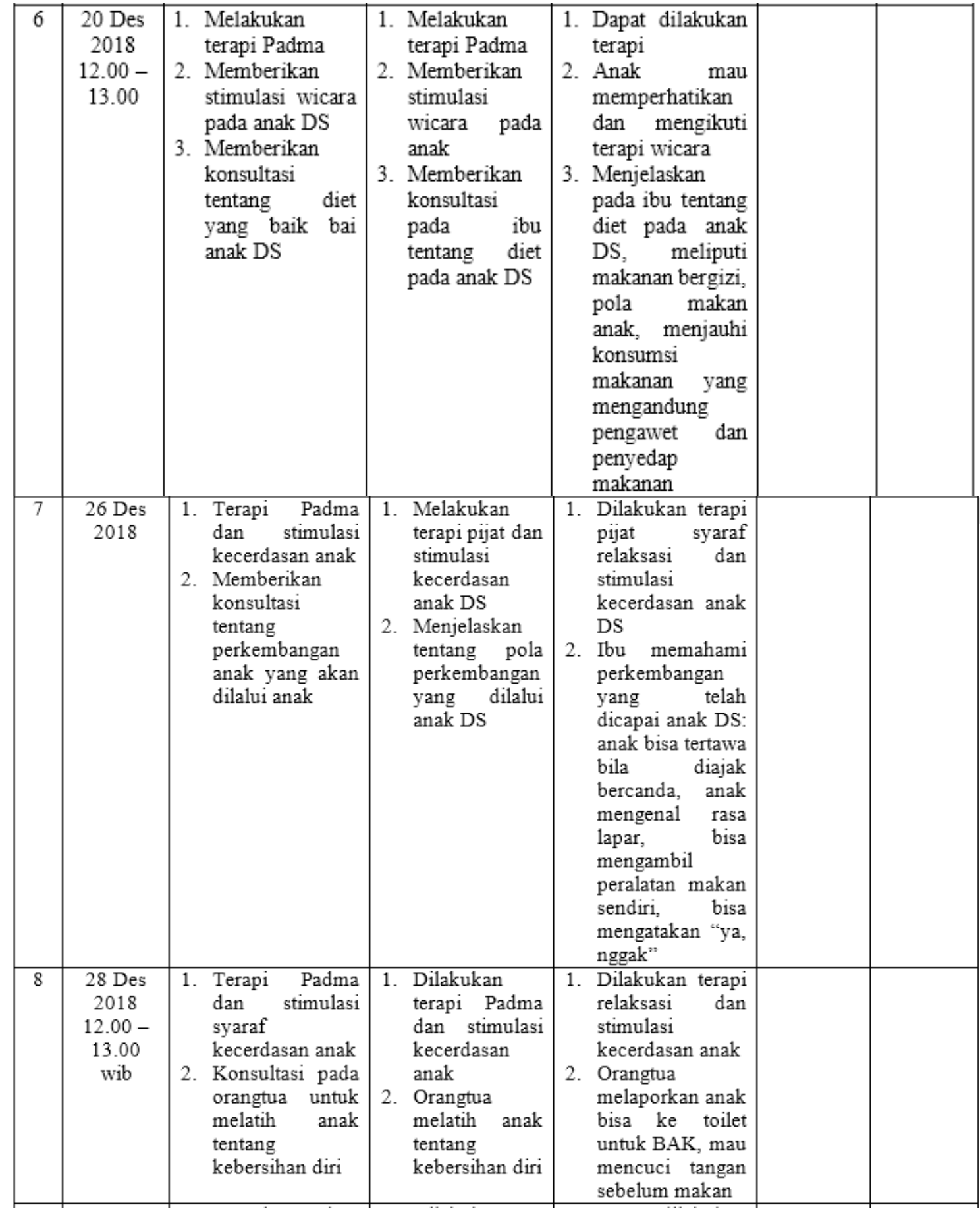




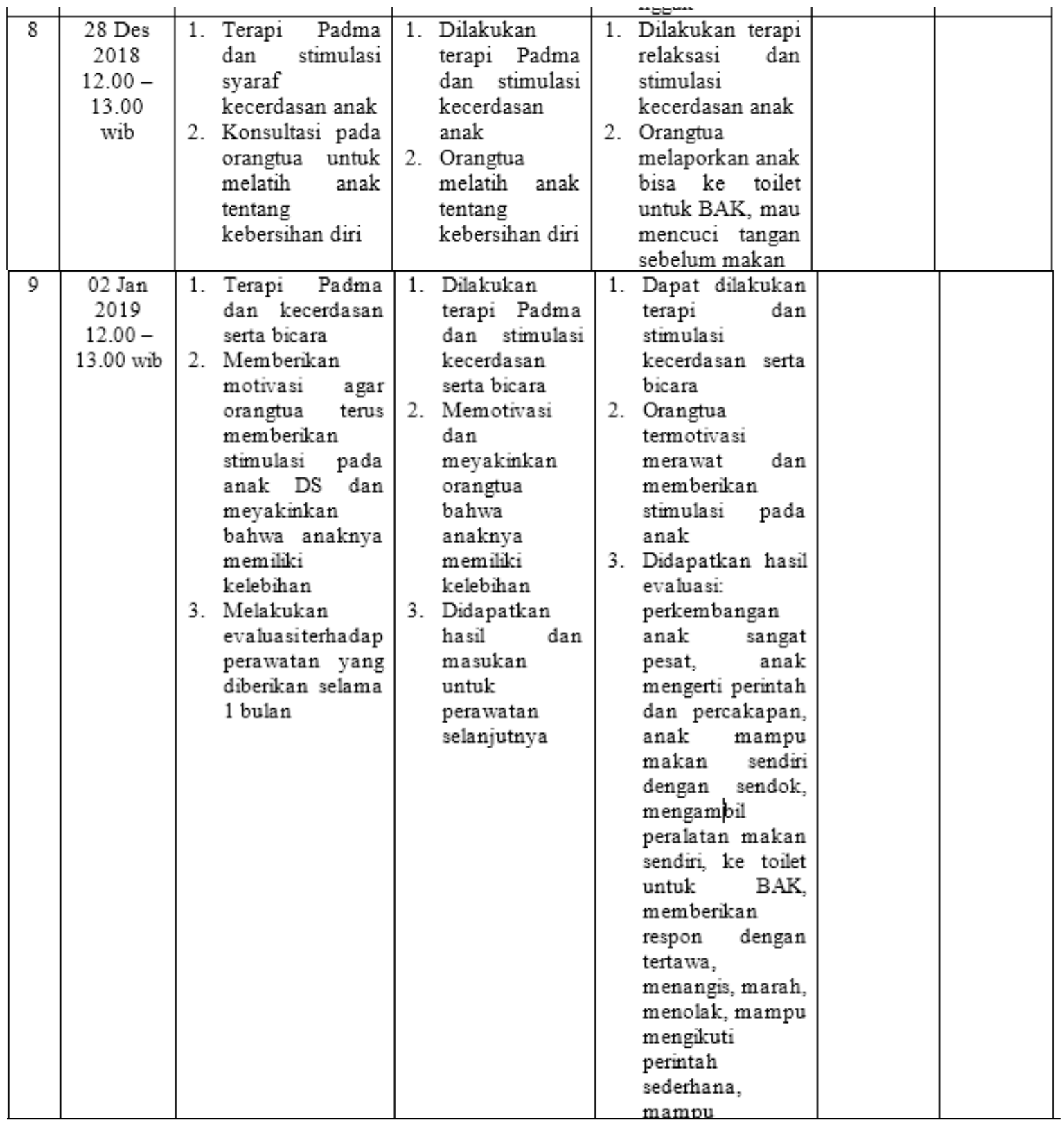


Studi Kasus: Penerapan Padma Sebagai Terapi Untuk Menstimulasi Tumbuh Kembang Anak Down Sindrom

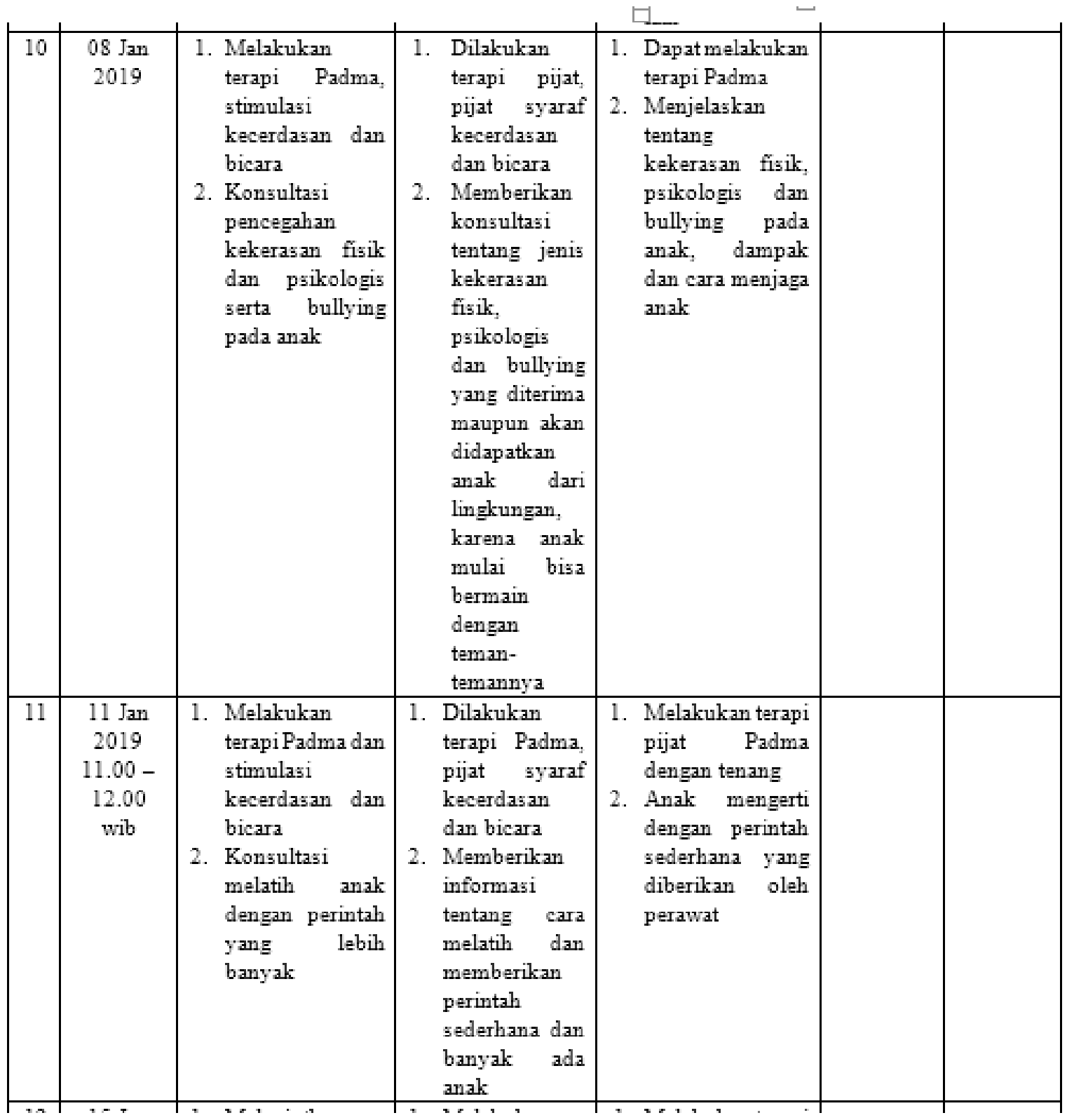




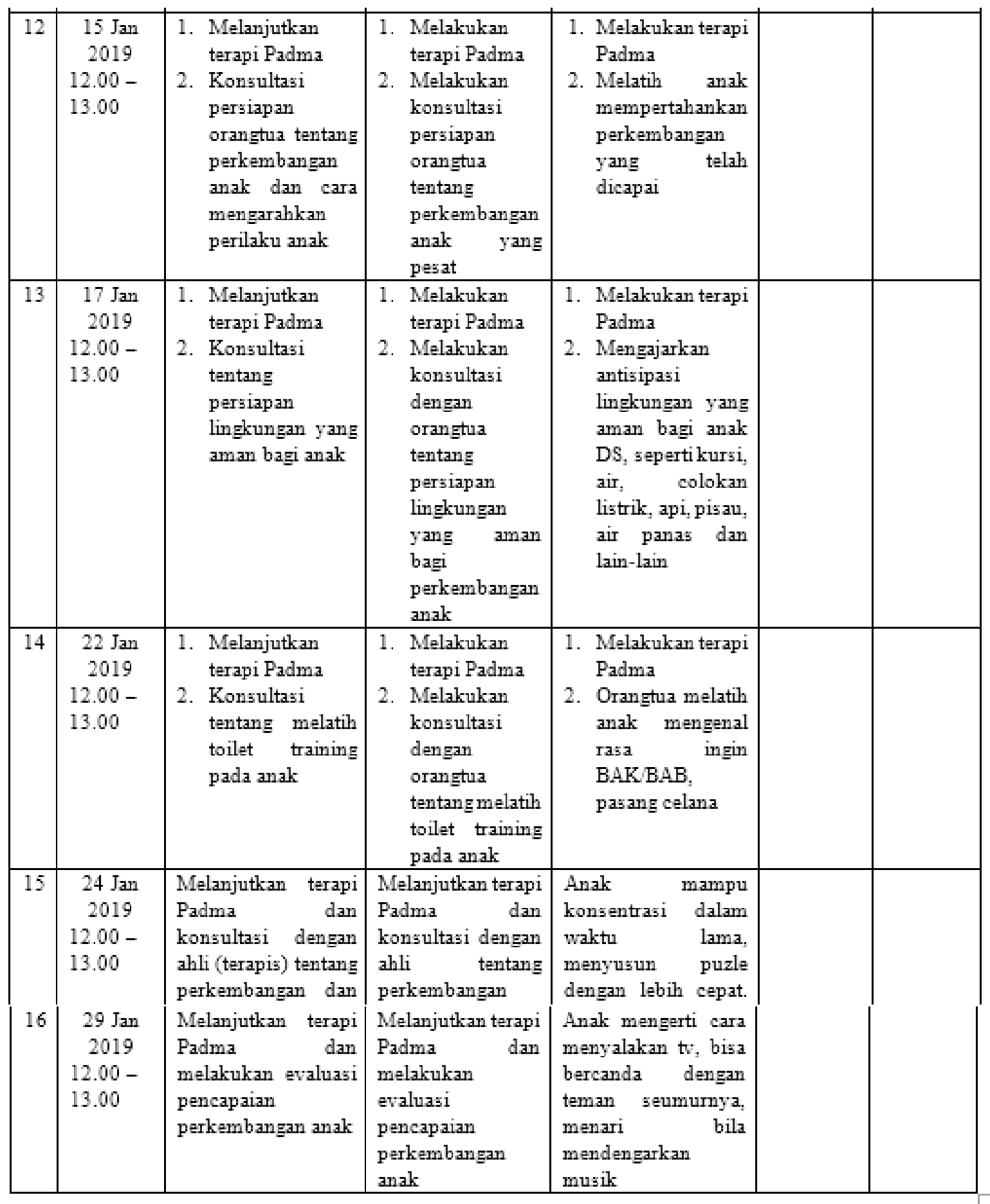


Studi Kasus: Penerapan Padma Sebagai Terapi Untuk Menstimulasi Tumbuh Kembang Anak Down Sindrom

\section{KESIMPULAN DAN SARAN}

1. Kesimpulan

Terapi Padma dapat digunakan untuk menstimulasi tumbuh kembang anak down sindrom

2. Saran.

Untuk keperawatan anak adalah sebagai tambahan implementasi dalam keperawatan untuk menstimulasi tumbuh kembang anak down sindrom. Untuk pendidikan sebagai media pengembangan ilmu pengetahuan khususnya ilmu keperawatan anak. Untuk keluarga sebagai salah satu terapi alternatif bagi anak down sindrom, bersifat praktis dan bersahabat dengan anak dan keluarga

\section{DAFTAR PUSTAKA}

Auckett, A.D. (2004). Infant massage. In encyclopedia children's health. http://www.healthofchildren.com/IK/Infant-Massage.html. diperoleh 9 Februari 2010.

Brownell, Daniel J. (2008). Massage contra indication.

http://www.ezinearticles.com. diperoleh 4 Maret 2010.

Coulter, Jacky. (1999). Benefits of massages for infants and mother. Journal Infant Mental Health, 25 , 1-3.

Cuncha. (1992). Gangguan Pemahaman Bahasa pada Anak Down Syndrome.www.txwicara.blogspot.com (Diunduh 28 Januari 2013).

Diego, M. A., \& Field T. (2009). Moderate pressure massage elicits parasympathetic nervous system response. International Journal Neuroscience, 119 (5), 630-638. Diperoleh tanggal 15 Desember 2014 dari http://informahealthcare.com/ doi/abs/10. 1080/ 00207450802329605.

Gunarhadi.(2005). Penanganan Anak Donw syndrom dalam lingkungan keluarga dan

sekolah.Jakarta : Dirjen Dikti Depdiknas.

Kozier, B., Erb, G., Berman, A., \& Snyder, S. J. (2010). Buku ajar fundamental keperawatan: Konsep, proses, dan praktik (7 ed., Vol. II). Jakarta: EGC

Masduki, Ali. (2019). Kelahiran down sindrom di Indonesia capai 3000 kasus.Minggu, 17 maret. 2017. https://jatim.sindonews.com/read/851 9/1/kelahiran-down-syn drome-diindonesia-capai-3000-kasus1552777424. Diunduh 12 juli 2019, pukul 14.00 wib.

Megasari, Intan \& Kristiana, Ika Febrian.(2016). Hubungan antara dukungan sosial suami dengan penerimaan diri pada ibu yang memiliki anak down sindrom.Jurnal Empati, Oktober 2016, volume 5 (4), 653-659.

Pardew, E. Michelle. (1996). The effects of infant massage on the interaction between high risk infants and their caregivers. United State: UMI Company.

Renawati., Darwis, Rudi Saparudin.,\& Wibowo, Heri. (2017). Interaksi anak down sindrom dengan lingkungan social (studi kasus anak down sindrom yang bersekolah di SLB Pusppa Suryakanti Bandung).Jurnal Penelitian \& PKM.Juli 2017.Vol 4, No. 2. ISSN 2442-448X (p), 25811126 (e).

Roesli, Utami. (2008). Pedoman pijat bayi prematur dan bayi usia 0-3 bulan. Jakarta: Trubus Agriwidya.

Weerapong, Pornratshanee., Hume, A. Patria., Kolt, S.Gregory. (2005). The mechanism of massage and effect on performance, muscle recovery and injury prevention. Sport Med journal, 35(3), 236-254

Zeisler, L. (2011). Assosiation between stress an decisional procastinations of children with down syndrome during their developmental transitions. New York : Seton Hall University. 